\title{
OPEN
}

Published online: 28 February 2020

\section{Publisher Correction: A comparative analysis using flowmeter, laser- Doppler spectrophotometry, and indocyanine green- videoangiography for detection of vascular stenosis in free flaps}

\author{
Thomas Mücke $\mathbb{D}^{\circ}$, Alexander Hapfelmeier, Leonard H. Schmidt $(\mathbb{D}$, Andreas M. Fichter $\mathbb{D}$, \\ Anastasios Kanatas, Klaus-Dietrich Wolff \& Lucas M. Ritschl
}

Correction to: Scientific Reports https://doi.org/10.1038/s41598-020-57777-2, published online 22 January 2020

The original version of this Article contained an error in the title of the paper, where the word "spectrophotometry" was incorrectly given as "|spectrophotometry". This has now been corrected in the PDF and HTML versions of the Article.

(c) (i) Open Access This article is licensed under a Creative Commons Attribution 4.0 International c. License, which permits use, sharing, adaptation, distribution and reproduction in any medium or format, as long as you give appropriate credit to the original author(s) and the source, provide a link to the Creative Commons license, and indicate if changes were made. The images or other third party material in this article are included in the article's Creative Commons license, unless indicated otherwise in a credit line to the material. If material is not included in the article's Creative Commons license and your intended use is not permitted by statutory regulation or exceeds the permitted use, you will need to obtain permission directly from the copyright holder. To view a copy of this license, visit http://creativecommons.org/licenses/by/4.0/.

(C) The Author(s) 2020 